\title{
Characters and ambivalence in Luke: An emic reading of Luke's gospel, focusing on the Jewish peasantry
}

\author{
Authors: \\ Mbengu D. Nyiawung ${ }^{1}$ \\ Ernest van Eck ${ }^{1}$ \\ Affiliations: \\ ${ }^{1}$ Department of New \\ Testament Studies, University \\ of Pretoria, South Africa \\ Note: \\ This article is based on the \\ $\mathrm{PhD}$ thesis, 'Who is the \\ Christ? Leadership and \\ conflict in Luke 9:18-22: \\ A social scientific- and \\ narratological analysis from \\ an African perspective', \\ submitted in 2010 in \\ the Department of New \\ Testament Studies, Faculty \\ of Theology, University of \\ Pretoria, with Prof. Dr Ernest \\ van Eck as supervisor.
}

\section{Correspondence to:}

Ernest van Eck

Email:

ernest.vaneck@up.ac.za

\section{Postal address:}

Department of New

Testament Studies, Faculty of Theology, University of Pretoria, Lynnwood Road, Hatfield 0083, South Africa

Dates:

Received: 12 Apr. 2010 Accepted: 19 Apr. 2011

Published: 11 Jan. 2012

How to cite this article: Nyiawung, M.D. \& Van Eck, E., 2012, 'Characters and ambivalence in Luke: An emic reading of Luke's gospel focusing on the Jewish peasantry', HTS Teologiese Studies/Theological Studies 68(1), Art. \#829, 12 pages. http://dx.doi.org/10.4102/ hts.v68i1.829

(C) 2012. The Authors. Licensee: AOSIS OpenJournals. This work is licensed under the Creative Commons Attribution License.
The Jewish peasantry as a character group in the Gospel of Luke has, thus far, not really attracted much attention in Lukan scholarship. In cases where it has been studied, scholars

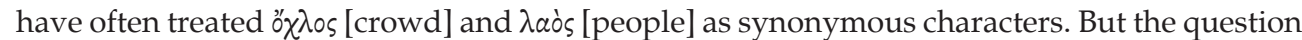
of Jesus' identity, as depicted in the New Testament, was crucial to the early church and it is this exact question that animates the relationship between Jesus and the various 'systems' functioning as part of Luke's Gospel. From an etic viewpoint, the context of Luke's Gospel indicates that Jesus' leadership was characterised by conflict, opposition and rejection. Therefore, this article attempted, through an emic reading of Luke, to differentiate between (and describe) the role played by each of these character groups in Luke's narrative, focusing on the relationship between Jesus and the Jewish peasantry - with special reference to the ambivalent attitude of the latter. It was argued that each Lukan character group has to be read and understood in terms of their attitude, as well as in the broader context of Luke's intention with their inclusion and specific description. Therefore the various terminologies used when referring to the Jewish peasantry were also discussed; for any analysis of a biblical character group should begin with a reading of the Greek text, because working only with translations can lead to a misappropriation of the text. In order to attain the goals as set out above, this study used a character group which seemed ambivalent and hypocritical in their attitude to analyse Jesus' leadership approach.

\section{General introduction}

One approach to understanding Jesus' story in the Gospel of Luke would be to analyse the various relationships that Jesus establishes with (and within) the different main 'systems' of 1st-century Palestine-namely, the Jewish elite, the Roman elite and the Jewish peasantry (Nyiawung 2010:139). But, when using this approach, it is important to keep in mind that Jesus as an individual also constituted a 'system' (cf. Boulding 1957:129), with the disciples (naturally) becoming or being a part of this 'system'. It is interesting to note that, for the most part, Jesus' relationships with the various 'systems' in the Gospel of Luke are relationships marred by suspicion, incomprehension, rivalry and malice - emotions manifesting as opposition and rejection, causing many of Jesus' relationships to be characterised as ambivalent in nature.

A few examples can be given: firstly, the Pharisees' attitude towards Jesus was a relationship that can be described as very unstable, as the Pharisees did not approve of Jesus' claim to being the Messiah. They expressed this disapproval with constant questioning in the form of challengeriposte (Lk 5:17-26, 29-39; 6:1-5, 6-11; 7:39-50) ${ }^{1}$ and by conniving with the scribes and planning and laying in wait for the opportunity to have Jesus killed (Lk 11:54). And yet, some of the Pharisees did show hospitality towards Jesus - in the form of fellowship meals (Lk 7:36; 11:37; 14:1-6) and by being (almost paradoxically) interested in his safety (Lk 13:31-33; 19:39). Here it is also appropriate and important to mention that Joseph of Arimathea - a member of the Sanhedrin - whilst not defending Jesus during his trial, did offer to bury him in the new grave he had recently acquired. Pilate, as another example, actually declared Jesus innocent at first (Lk 23:4, 14-22), but then had to offer him up to be crucified in order to prevent rioting, thus exhibiting extreme powerlessness and fear of rejection (Lk 23:24). Along that line, Herod - who had earlier manifested the intention to destroy Jesus (Lk 9:9; 13:31-33) - now became excited and wanted to see Jesus perform signs (Lk 23:8). And, although the centurion did not follow Jesus, he endorsed his identity as innocent and righteous at the moment of Jesus' death (Lk 24:47).

One of the most important relationships described in the Gospels is the relationship between Jesus and his disciples - and, even though Jesus' disciples showed enthusiasm in their new mission (Lk 5:11, 28; 11:2; 17:5), they did sometimes still become wayward (Lk 8:22-25; 9:10-17),

1.The exercise of challenge-riposte was an act of social communication whereby the public arbitrated in a confrontation between two equals. It was a process by which honour was either publicly acknowledged or despised. Consequently, the claim to honour that was not publicly recognised was seen as foolish (Rohrbaugh 2007:32). 
even abandoning Jesus during his trail (a sign interpreted as rejection). Of course, one of his disciples - Judas Iscariot betrayed him by identifying him for the Temple soldiers (Lk 22:47) and the rest of the disciples then abandoned him during his arrest, trail and crucifixion. Peter, who had promised to be loyal and who did actually go to Jesus' trial, broke his promise of loyalty unto death for the sake of personal safety.

But the most striking example of this ambivalent attitude within a relationship with Jesus can be found in his relationship with his peers, that is, the Jewish peasantry. In Nazareth they accepted him when he presented his manifesto (Lk 4:22). But, not long thereafter, they rejected him when they realised that this manifesto or agenda was not what they had thought or believed it to be (Lk 4:29). Karris (1979:28) remarks that this recurrent pattern of acceptance and rejection is already alluded to at the very beginning of the Gospel with Simeon's prophecy (Lk 2:34-35) and is carried through to the very end of the Gospel with the re-enactment thereof at the end of Jesus' ministry - when God accepts Jesus after his seeming 'rejection' on the cross.

It is this pattern of ambivalence in the Gospel of Luke, especially as it is portrayed by the Jewish peasantry, that serves as the focus of this study and is motivated by two main issues. Firstly, some scholars argue that the Jewish people expected a Messiah who would eventually free them from Roman oppression. Interestingly, although Jesus was born into the Jewish faith from a lowly peasantry family (Oakman 2008:164), his peers (the very same Jewish peasantry into which he was born) did not lend him their support (cf. Neyrey \& Rohrbaugh 2008:243). Secondly, up to the passion narrative in Luke, the Jewish peasantry seems to have (generally) been loyal to Jesus. So is the crowd rejecting Jesus and demanding his crucifixion at the end of the Gospel the same crowd that followed Jesus loyally in Galilee? And, if so, why did they reverse their attitude when Jesus was arrested, judged and crucified?

In what follows, the issue as set out above will be dealt with in the following manner: firstly, attention will be given to Luke's description of the Jewish peasantry, as well as to Luke's portrayal of their relation to Jesus. Following this, the Jewish peasantry's ambivalent attitude towards Jesus will be analysed. Finally, Jesus' role and actions, in the midst of these 'hypocritical' peers, will be studied.

\section{A definition of terms and a description of the current debate Definitions}

In this work ambivalence is understood to be referring to a situation of uncertainty, marked by an attitude which oscillates between acceptance and rejection; in other words, a state of tension (characterised by dissonance) which generally occurs when an individual holds two or more psychologically inconsistent cognitions (Budjac Corvette 2007:169; Tyler 2005:14). In this study, ambivalence will be used to describe the indecisive nature of the Jewish peasantry when either accepting or rejecting Jesus.

The term emic (coined by Gottwald [1979:785] and borrowed from language theory) relates to the way in which a reading is carried out - it thus describes the perspective from which any analysis or interpretation is carried out. The term emic is related to 'phonemics' - categories of thought and explanations as given by the group that is being studied (Elliott 1993:129); it is an anthropological term which refers to the report of a narration from the 'natives' point of view and is a cognitive pattern of what is supposed to happen (which includes what actually happens; Moxnes 1991:251). Etics, on the other hand, is related to the word 'phonetics' (i.e. the science of speech sounds) - in other words, how an external investigator classifies systems different from his or her own; thus referring to an analysis from an outsider's point of view and making use of theories or models formulated by this person (the exegete) in order to facilitate understanding (Van Eck 1995:163; cf. Van Aarde 2006:367). Thus, the emic reading used in this study is a reading that re-narrates the relationship between Jesus and the Jewish peasantry from the insider's viewpoint (Nyiawung 2010:125; Rosell 2008:56).

According to some social-scientific interpreters or scholars (e.g. Esler 1989:171-175; Oakman 2008:143-144; Rohrbaugh 2007:155), the context in which the Gospel of Luke was written was that of a stratified society - the rich and the powerful (whether economically, politically and/or religiously) constitute the 'haves' or the elite, whilst the peasantry made up the 'have-nots' or the disadvantaged (Beavis 1997:142). The peasantry were thus considered as those at the very bottom of society: for Beavis (1997:147), this includes the 'infirm' and 'the sick' (Lk 7:22-23), as well as the 'ethnic and religious outcasts' such as the Samaritans (Lk 9:52; 10:33; 17:16) and the Gentiles (Lk 2:32; 4:26-27; 7:2-10). Mary's Magnificat refers to them as those of 'low degree' and 'the hungry' (Lk 1:52-53). Jesus also categorises them as the 'poor', 'the captives', 'the blind', 'the oppressed' and those who 'weep' (cf. Lk 4:18; 6:21). In the Gospel of Luke, these peasants rebel against (are opposed to) those who are referred to as 'full', those who 'laugh' and are spoken well of (Lk 6:25-26). They are also opposed to 'the rich' (Lk 6:24; 12:13-21; 16:19-31; 18:18-30; cf. also Lk 13:33; 14:12-14; 16:9). ${ }^{2}$ As Jesus comes from an equally 'low background' (Neyrey \& Rohrbaugh 2008:243; cf. Lk 2:7, 24; 4:16-30), he knows the plight of this group of people very intimately; therefore opting to offer them a new status (Esler 1989:187).

In a nutshell, the peasantry in the Gospel of Luke are described and viewed as the 'common people', the people who 'seemed to have lost the sense of being human as a result of some natural or man-made circumstances' (Nyiawung 2010:174). This peasantry most probably

2.These terms - such as poor, rich, hungry, captive, blind and oppressed - do not necessarily need to be taken literally for they also have a spiritual symbolism in necessarily noed to be taken literally, for they also have a spiritual symbolism in Jesus' thought form (Beavis 1997:144-148). However, Jesus seemed to have used these terms in both senses; Luke's description of these concepts implies not only a lack of physical or spiritual resources, but also refers to social standing and the inability to meet social requirements (Malina 2001:92; Moxnes 1988:103) It is interesting to note that Jesus' healings were not directed only at this or any particular stratified group of people, as the literally rich and powerful also benefited. 
consisted of exploited fishermen, craftsmen and farmers; all forming part of an advanced agrarian society, a society in which the 'non-elite' lived a life of dependency that arose from the economic, social and political situation imposed on them by an aristocratic society (Oakman 2008:11). In Luke's Gospel, the peasantry is identified as the o' $x$ os ['crowd'], the $\lambda$ aòs ['people'] and sometimes simply referred to as $\pi \tilde{\alpha} \varsigma$ ['all'] in the narrative. Most Lukan scholars understand and believe these characters to be synonymous, but below it will be argued that these terms are not meant as synonymous by Luke but rather that they constitute the 'system' of the Jewish peasantry in the Gospel of Luke.

\section{Current debate}

\section{The understanding and use of the terms ${ }^{\prime \prime} \chi \lambda \circ \varsigma$, $\lambda \alpha \dot{s} s$ and $\pi \tilde{a} s$ in the Gospel of Luke}

There is a clear distinction in Luke's usage of the terms

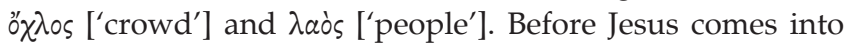
contact with the ob $\chi$ os and the $\lambda$ aos (the two main groups of peasantry in the Gospel), Luke mentions another character

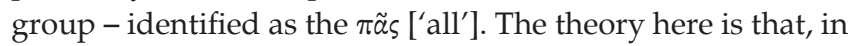
Luke, Jesus' encounter with these different character groups is meant to serve as an indication of the way in which he should be identified and understood. Consequently, any understanding of the relationship between Jesus and the peasantry will be influenced by the understanding of the differences embedded in these distinctive terms (as used by Luke). Therefore, in the following section, Jesus' relationship with the peasantry will be defined and described in terms of his relationships with the ob $\chi \lambda \circ \varsigma$, the $\lambda$ à่s, as well as the $\pi \tilde{\alpha} \varsigma^{3}{ }^{3}$

In the Revised Standard Version (RSV) of the Gospel of Luke

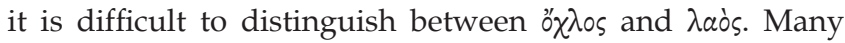
scholars have fallen victims of that error, including RSV translators. ${ }^{4} \mathrm{RSV}$ (rightly) identifies $\lambda$ aòs as 'people', whilst, conversely, "o $\chi \lambda \circ$ s is offered multiple translations. It is either referred to as 'multitude' (Lk 3:7, 10; 5:15; 8:45; 12:1, 13, 54; 14:25; 19:39; 23:4, 48), 'company of' (Lk 5:29) or 'people' (Lk $4: 42 ; 5: 1,3 ; 9: 18 ; 11: 14 ; 13: 17)$, defeating the purpose of a word having one specific meaning in order to be a vehicle of communication (cf. Beidelman 1970:30; Nyiawung 2010:127). Quite often, $\pi \lambda \tilde{\eta} \theta \circ \varsigma$ is also used to refer to a 'multitude' (Lk $1: 10 ; 2: 13 ; 5: 6 ; 6: 17 ; 8: 37 ; 19: 37 ; 23: 1 ; 23: 27)$ - in this case, it is a quantifying adjective. The Nestle-Aland, 27 th edition uses $\pi \tilde{\alpha} \varsigma$, which goes beyond any specific distinction to mean 'all' (Lk 4:15, 22, 36, 40); probably referring to a mixture of both the

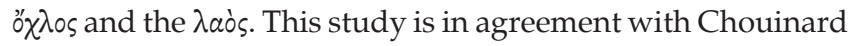
(1997:68) who states that the Bible contains a verbal reality; that is, that meaning is only communicated through sound understanding and interpretation.

It is interesting to see that a study of the understanding of the difference in Luke's use of the terms ó $\chi \lambda$ os and $\lambda$ aòs has drawn little or no attention in Lukan scholarship; a neglect probably

3.Luke's Gospel uses of $\lambda$ os and $\lambda a o^{\circ}$ in both the singular and the plural. For the sake of simplicity, both nouns will be used either in the nominative singular or in the nominative plural, irrespective of the cases in which they appear in the Greek text.

4.The Greek New Testament Text used in this article is the Nestle-Aland, 27th edition. influenced by the available translations of the text. Also, in the works of several Lukan scholars - such as Desjardins (1997), Esler (1989), Goheen (2005), Green (2005), Sanders (1987), Spencer (2005) and Wenham (2005) - it becomes apparent that o' $\chi \lambda \circ$ s and $\lambda$ oòs are used interchangeably to refer either to 'people' or to mean 'the crowd'. Serving as an illustration are the works of Dahl (1958), Karris (1985) and Tyson (1986), which will be examined briefly, for, beyond using these terms as synonyms, these authors have also raised pertinent issues concerning the understanding of Luke's use of the

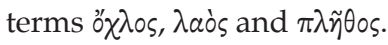

Dahl (1958:324) argues in more general terms that, apart from Acts 15:14 and 18:10, Luke is always referring to Israel when he uses $\lambda$ à̀s. But he also makes the statement that $\lambda$ aòs does not always have the full theological meaning of 'the people of God' as a contrast to the Gentiles; in many cases Luke simply uses it as a synonym for ö $\chi \lambda$ os (Dahl 1958:324). Therefore, according to him, גaòs is a 'vulgar' usage that is found in contexts where the people referred to are a crowd of Israelites. Karris (1985:111), in his turn, establishes a

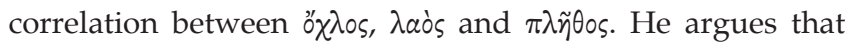
'multitude' in Luke is an equivalent to 'crowd' and that both are equivalent to 'people'. He is also of the opinion that the people who demanded Jesus' crucifixion (Lk 23:13-25), those who watched how he died (Lk 23:35) and those who responded to his death (Lk 23:48), were identical in character. In contrast, Tyson (1986:31) views the $\lambda$ aòs as those who accept Jesus and John the Baptist, whilst the Jewish public is identified as o' $\chi \lambda$ os. So for him, o' $\chi \lambda$ os is used to refer to the masses of indeterminate and unidentified Jewish people. He argues that Luke uses $\lambda$ aò frequently, but that, at times, he also uses o' $\chi \lambda$ ros. His conclusion: that when Luke refers to typical Jewish people he uses o' $\chi \lambda \circ s$, but when it is about a mixture of people, he uses o' $\chi \lambda$ os (Tyson 1986:33).

So, Karris and Tyson thus seem to disagree with Dahl's understanding of $\lambda$ aòs - as referring to Israel and as distinct from the Gentiles. Dahl, however, needs to be understood from his context and the objective he has, namely his focus on Acts. In Karris's understanding, there seems to be some confusion between the $\lambda$ às of Luke 23:13-25 and the $\lambda$ à่s

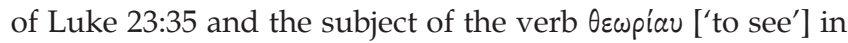
Luke 23:48, with the $\lambda$ à̀s of Luke 23:13-25 most probably being the same $\lambda$ aos that we find in Luke 23:35. However, this configuration changes in Luke 23:48, where Luke refers

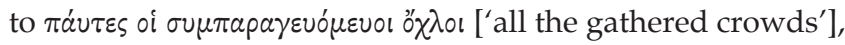
which would be wrongly translated as meaning $\lambda$ a s̀ (cf. Karris

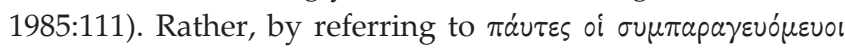
" $\chi \lambda$ ol, Luke takes into account the story line that has been evolving from Jesus' arrest (Lk 22:47). It therefore seems erroneous to refer to the ó $\chi \lambda$ or in the expression $\pi a ́ v \tau \varepsilon \varsigma$ of

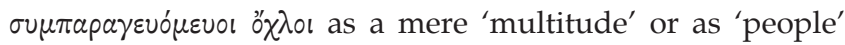
(see Karris 1985:111), as, obviously, the characters involved in the verses mentioned by Karris cannot be the same character group referred to in the Gospel. 
Concerning Tyson's argument - it seems that he simply does not take into consideration the fact that, apart from o' $x \lambda$ or and $\lambda a \dot{s}$, Luke uses the terms $\pi \tilde{\alpha} \varsigma$ and $\pi \lambda \tilde{y} \theta 0 \varsigma$ equally and in a very precise manner. In his identification of the $\lambda$ aòs as those who accepted Jesus and John the Baptist, Tyson surely has Luke 7:24-30 (and especially Lk 7:29) in mind; but Luke 7:24-3 is an isolated and dependent pericope in Luke's narrative that begins with Jesus addressing the o' $\chi \lambda$ or (Lk 7:24). Those who appear to accept Jesus in Luke 7:29 include 'all the people' and the tax collectors. This distinction is not accidental, especially when taking into consideration that both these character groups belong to the same 'system' - otherwise labelled the Jewish peasantry. Tyson does not also seem to take into account the fact that Luke already used o' $\chi \lambda$ os when referring to those who listen to John (Lk 3:7) and those who will eventually listen to Jesus (see the section entitled 'Jesus and the 'ox $\lambda$ os' below). It thus seems premature for Tyson to come to any definite conclusion based on Luke's understanding and use of the word $\lambda$ aos only.

In short, apart from being a literary piece (Spencer 2005:114; see also Resseguie 2005:19), Luke's Gospel is about biblical historical facts (Awoh 2003:55; Karris 1979:5) addressed to Theophilus (Lk 1:1-4). Because of the latter, the author of the Gospel of Luke demonstrates a sense of accuracy and precision in his choice of words when writing. In the next section it will be argued that an emic reading of Jesus' relationship with the "ox $\chi \lambda \circ s$, the $\lambda$ às and the $\pi \tilde{a} s$ can offer a possible solution as to the way in which the Gospel of Luke should be read and understood in this regard.

\section{An emic reading of the relationship between Jesus and the Jewish peasantry in the Gospel of Luke}

As explained above, an emic reading of Luke is a re-narration of Jesus' story focusing (inter alia) on Jesus' relationship with the various character groups that constitute the 'system' of the Jewish peasantry (the o' $\chi \lambda \circ \varsigma_{\text {, the }} \lambda$ aòs and the $\pi \tilde{\alpha} s$ ), from the point of view of the 'native' - the reader(s) that is a part of the context or the world of Luke's Gospel.

\section{Jesus and the ö $\chi \lambda \circ \varsigma^{\circ}$}

The noun ${ }^{\prime} \chi \lambda$ ㅇs appears for the first time in Luke 3:7 and here refers to a distinct group seeking admission into a new movement led by John the Baptist. Henceforth, the o' $\chi \lambda$ os are those who listen to John's teaching. In Luke 4 Jesus begins his ministry, after news about him has spread throughout the surrounding country (Lk 4:14-15, 37); a spread most probably effected by the announcement of his ministerial plan or activities (in Lk 4:18-19), combined with its effective realisation in Capernaum and beyond. Those who sought him out are the o' $\chi \lambda$ os (see Lk 4:42) and are perhaps members of the category who have been healed and liberated by Jesus, announced in Luke 4:18 (see also Lk 4:39; 7:22; 18:43).

Jesus continues his ministry towards the o' $\chi \lambda$ os from Luke 4:42 onwards, until these o' $\chi \lambda$ os are joined by the $\lambda$ aò $s$ for the first time in Luke 6:17. Here, o' $\chi \lambda$ os is then identified in reference to the disciples, whilst $\lambda$ aòs probably refers to the anxious, enthusiastic and desperate inhabitants from Judea, Jerusalem and the seacoast of Tyre and Sidon. Up to this point, Jesus' disciples had been known specifically to be his 'apostles', but, in Luke 6:17, they now become part of a larger organised and conscious entity or group who are following Jesus. This o’ $\chi \lambda$ os continues to swell in numbers as a result of Jesus' teaching and miracles - apart from those who are physically healed, sinners and tax-collectors now also become a part of the o' $\chi \lambda$ or. The ${ }^{\prime} \chi \lambda$ or thus consist of a completely new community. In Jerusalem, they are Jesus' sympathisers (Lk 19:39); a strong force to reckon with - accentuated by the fact that Judas wishes to betray Jesus only when they are absent (Lk 22:6). This o' $\chi$ 入 0 s reappears in Luke 23:48, and resumes its initial meaning as members of a conscious group when they beat their breasts after the centurion's declaration. It thus seems that the $\lambda$ aos has fused with the o' $\chi \lambda$ os to become one group.

The distinction between o' $\chi \lambda$ os and $\lambda$ aòs is sharper in Luke 6:17 and 19. Firstly, there is an óx $x$ os of disciples and, secondly, there is a $\lambda$ à s consisting of all the people joining Jesus from the areas of Judea, Jerusalem and the seacoast of Tyre and Sidon. Both these groups come to listen to Jesus and to be healed of their illnesses (Lk 6:17). Interestingly, after their need has been attended to by Jesus, they are all now identified as the o' $\chi$ \os that sought to touch Jesus (Lk 6:19). This distinction is also clear in one of the charges levied against Jesus - he is accused of misleading and stirring up the $\lambda$ aìs, not the ob $\chi$ os (Lk 23:5, 14). An obvious charge would have been that he misled and stirred up the o' $\chi \lambda$ os who was following him; but, instead, Jesus is charged for derailing the $\lambda$ aòs, who probably symbolise Israel as a nation. The religious authorities thus realised that Jesus was destroying the community of the $\lambda a$ ò (this distinction will be demonstrated below), in favour of a new community - the o' $\chi$ גos.

\section{Jesus and the $\lambda \alpha$ òs}

The term $\lambda$ às appears for the first time in Luke 1:10, referring to devoted Jews or people of the Jewish faith. The use of the term $\lambda$ às continues unchanged up to Luke 3:7 (though Jesus himself is already introduced earlier in the narrative), where Jesus' new community of followers is called the " $\chi \lambda$ ○s. In between these two points, Luke introduces another character group, simply identified as $\pi \tilde{\alpha}$ (Lk 4:15, 22, 36, 40) a group distinct from the $\lambda$ aios and the o' $\chi \lambda$ os in terms of their relationship with Jesus. However (as stated above), the o' $\chi \lambda$ os of Luke 3:7 are members who will eventually be initiated into a new community by John the Baptist. Consequently, in Luke 3:21, they are baptised as $\lambda$ às.

In Luke 6:17, $\lambda$ aòs reappears with a new and second meaning - it is used to describe those who have come from Judea, Jerusalem, and the seacoast of Tyre and Sidon; probably implying a mixed group (i.e. Jews, devoted or not). This same group is later mentioned during the trail of Jesus, where they actively participate. The term $\lambda$ aòs is used again (finally) in Luke 24:19, confirming that the author of the Gospel of Luke uses this term in an exclusive manner to refer to believers 
of the Jewish faith, in particular, and the people of Israel as a race, in general. According to the two disciples on their way to Emmaus, Israel's hope had been built on Jesus as its liberator. In the passion narrative, the $\lambda$ aòs are those whose interests the religious authorities are seeking to protect. They constitute the nation of Israel. The charge brought against Jesus - namely his stirring up and perverting of the $\lambda$ aòs (Lk 23:5, 14) - should be understood in this sense. But, supposedly, it is specifically for their sake that he has come (Lk 24:19); an understanding further bolstered by the fact that Luke identifies some of the authorities only in relation to the $\lambda$ aos: 'the principal men of the $\lambda$ aòs' (Lk 19:47) and the 'elders of the $\lambda$ aòs' (Lk 22:66).

\section{Preliminary conclusions regarding Jesus' relationships with the "ox $\chi 0 \varsigma$ and the $\lambda$ aòs}

A closer look at Luke 9:13, 22:47 and 23:4 can serve as a conclusion for the above discussion of Luke's understanding of the distinct relationship between Jesus and these different groups - the o' $\chi \lambda$ os and the $\lambda$ aòs. Whilst in Bethsaida, when the disciples realised that it was getting dark, they beckoned to Jesus to send the o' $\chi \lambda$ os away (Lk 9:12); seemingly out of concern for the o' $\chi \lambda \circ$ s, as, when Jesus challenges their request, the disciples seem to become upset because of their inability to feed the o' $\chi \lambda$ os. So what started as concern for a group (the b $\chi \lambda \circ \varsigma$ ), seems to end in shame and uneasiness for the disciples. More importantly, this reaction dissociates them from the group that Jesus challenged them to feed; a fact that becomes even clearer in their reference to the o' $\chi \lambda$ os as the $\lambda$ aòs in Luke 9:13. Later in the story, Jesus corrects this misconception after he had blessed the loaves and the fish, he gave them to the disciples and ordered them to set the food before the o $x$ 소 (Lk 9:16); thus, the availability of provision has caused the audience to assume its normal appellation as ö $\chi \lambda$ os.

In Luke 22:6 it is reported that Judas had agreed to betray Jesus, but then only when the o' $\chi \lambda$ os is absent. But the idea or the definition of the o' $\chi \lambda$ os then becomes ambiguous; for

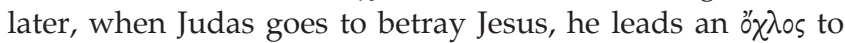
arrest Jesus (Lk 22:47). ${ }^{5}$ Two possible reasons could be given as explanation for this apparent contradiction: the first comes from the composition of the ob $x$ os in Jerusalem at the time of Jesus' arrest. Horsley (1993:95) remarks that, ordinarily, the crowd was a mass of common people from both the rural and the urban areas - all poor and therefore also economically dependent. Jesus' arrest coincides with the period of the Passover festival in Jerusalem; a period in which the citizens of Jerusalem were joined by thousands of pilgrims from the surrounding towns and villages. This means that pilgrims at the Passover festival might have heard and seen Jesus, without it necessarily meaning that they had had a personal

5.Traditionally, the term o $x$ d os or 'crowd' could have a negative connotation, especially when used to refer to a mob. Horsley (1993:95) reports that Josephus described these 'crowds' as 'rebels'; citing many different cases as examples: the thousands of workers who rioted because they became unemployed after the completion of the Temple in Jerusalem; the mob that rose against Pontius Pilate because he had images of Caesar erected in Jerusalem by night, for the interest of public worship images of Caesar erected in Jerusalem by night, for the interest of public worship - considered to be a provocation to the worship of God. However, even though the crowd was known to be a social pressure group, they were not really revolutionary because they did not challenge the system; they simply stood against its abuse of power. In Jerusalem they were a constituted group that often stood against the poor treatment that they received from their rulers. So, in the absence of legitimate channel (or vehicle) through which the ordinary people could express their grievances, this rebellion or outcry from the crowd served that purpose. experience with him (Borg 2006:232). But this then also means that the authorities would have been able (easily) to convince these same people to revolt against Jesus (Nyiawung 2010:148). The 'crowd' in Luke 22:47 therefore does not appear to be the same animated crowd (with enthusiasm and anxiety) from earlier on in Jerusalem.

Secondly, Judas Iscariot - as one of Jesus' apostles - had also been a part of the o' $\chi$ 入 0 s. But his identity obviously had become distorted when he went into negotiations with the authorities to betray Jesus. Nyiawung (2010:176) is of the opinion that it might have been customary (in 1st-century Palestine) for political and religious authorities to manipulate people in such a way as to cause them to act in their (the manipulator's) favour. Along that line, Horsley (1993: 96) also affirms the fact that - quite often - there was a symbiosis between the Jerusalem 'crowd' and its 'king'. As an example he mentions the case of the 'crowd' that stood for Cumanus in 4 BCE. On the fourth day of the festival a Roman soldier stood naked, exhibiting his genitals to the multitude; an action that created anger and rage with onlookers, who considered this attitude to be an offence against God (or blasphemy; see Horsley 1993:97). Hence, instead of standing in defence of the right of the populace, the crowd stood on the side of Cumanus because they interpreted his attitude religiously.

The manipulation of the ${ }^{\prime} \chi \lambda$ 소 character in the Gospel of Luke begins when spies attempt to entice them (the 'group') into standing or rebelling against Jesus (see Lk 20:2). ${ }^{6}$ And, with this as background, we begin to understand that the o $\chi \lambda$ ○s in Luke 22:47 was just as manipulated and distorted as Judas himself was - because the authorities feared Jesus' audience, they might have considered it best to manipulate his closest followers (i.e. Judas and the o'x $\chi 0 \varsigma$ ) in order to gain access to him. With this being the case, Luke might have wished to use this to show that, although the o' $\chi$ hos followed Jesus, their conception of Jesus' identity was uncertain; in this way describing the ambivalent character of the o' $\chi \lambda$ os as part of the group that followed Jesus.

The nature of the relationship between Jesus and both the

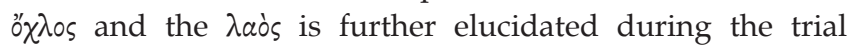
narrative. According to Luke's narrative, Pilate reported on Jesus' innocence to both the chief priests and the "' $\chi \lambda$ os ( $\mathrm{Lk}$ 23:4), but they kept pressing hard on the charges against him. For the strengthening of the case against Jesus, the o' $\chi \lambda$ os were convinced to act as false witnesses (and thus as accomplices). However, the situation is rectified when Pilate later convenes the chief priests, the rulers and the $\lambda$ às - but not the ob $\chi \lambda \circ s_{-}$ for his final verdict ( $\operatorname{Lk} 23: 13)^{7}$; which means that even Pilate seems to have understood that those who were particularly affected by Jesus' teaching (according to the new charge brought against him) were the $\lambda$ aòs (Lk 23:5, 14).

6 .In Acts 6:13 false witnesses were also prepared to witness against Stephen.

7.Cassidy (1983:151) and Fitzmyer (1985:1484) agree that if Pilate had brought in the " $x$ 入 0 s earlier (Lk 23:4), it was for the purpose of reducing the pressure being put on him by the priests. But this is only conjecture, conjecture which does not seem to be accurate - the o ' $\chi \lambda$ os had already been part of Jesus' arrest (Lk 22:37) and, before his trial had even begun, they stood as distorted opponents of him. It could thus be argued that, just like Judas, they might have been determined to pursue their be argued that, just like Judas, they
perceived assignment to the end. 
Thus, the 'ox $x$ os are not party to Jesus' trail and execution anymore; no, those who do demand that Jesus be crucified - and who revel in it - are the chief priests, the rulers and the $\lambda$ aòs (Lk 23:16, 21). Later on in the narrative the author of the Gospel of Luke reports that, even though a multitude of $\lambda$ ais followed Jesus, only the women wailed and lamented (Lk 23:27). In the end, the $\lambda$ aòs of Luke 23:27 simply become the of $\chi$ os in Luke 23:48, perhaps a sign that they - in the mean time - had been convinced that Jesus was effectively dixalos ['righteous'].

A few preliminary conclusions can be drawn from the analysis above. Firstly, that the author of the Gospel of Luke's use of the terms $\lambda$ às and o' $\chi \lambda$ os should be understood in terms of being an expression of the universality of Jesus' mission. Secondly, the author's usage of the terms should be linked to (or understood in terms of) knowledge of Jesus' true identity, both prior to and after a personal experience of him and his activities. Thirdly, the author wishes to show that, irrespective of any character group, some members within each of the different groups served as foils to the other members. Fourthly, the author intends to show his audience that the Gospel begins with $\lambda$ aòs (Lk 1:10) and ends with $\lambda$ ais (Lk 24:19).

But, despite all of the above, Jesus still commissions his own disciples and then not just to the $\lambda$ aòs or the o' $\chi \lambda \circ s$, but to the

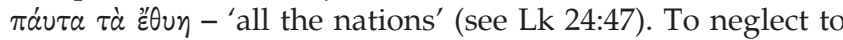
recognise and acknowledge these aspects of the Lukan text leads to a misinterpretation and misunderstanding of both the author's intention with the Gospel of Luke, as well as his rich use of terminology. For example, Via (1983:131) has remarked that 'although the crowd ('ox $x \circ 5)$ sometimes participates in Jesus' death, other crowds ('o $\chi \lambda \circ)$ gather at the cross, and return home beating their breasts after Jesus dies (Lk 23:48)'. This remark is misleading exactly because of the fact that Luke defines o' $\chi \lambda$ os and $\lambda$ aòs in a very specific way, especially when it comes to their relationship with Jesus.

\section{Jesus and the $\pi \tilde{\alpha} \varsigma$}

Jesus' ministry is launched by reports about him spreading through the surrounding countryside ${ }^{8}$ (Lk 4:14) - in this his victory over the devil in the wilderness seems to serve as both a merit and as confirmation of the fact that he is the Son of God (cf. Lk 3:22); thus having an impressive impact on those referred to as the $\pi \tilde{\omega} s\left[{ }^{\prime}\right.$ all'], ${ }^{9}$ for they now become a vehicle for Jesus' praise, glory and fame as he travels to and teaches in their synagogues (Lk 4:15). Jesus' travelling and teaching soon take him back to Nazareth, where he (of course) reads from the Isaiah scroll - in doing so he seems to have once again impressed the $\pi \tilde{a} \varsigma$ with his announcement of the content

8.Oakman (2008:132-163) is correct when arguing that Jesus' mission in Luke's Gospel essentially took place in the 'countryside'; an idea bolstered by the fact that LukeActs contains $60 \%$ of the New Testament's vocabulary that refers to the 'country' or the 'rural precinct' (Oakman 2008:132). In Luke's Gospel, 'country' is used either to refer to countryside (Lk $1: 39-40 ; 2: 8 ; 4: 14 ; 11: 5-8 ; 12: 16-21 ; 15: 19 ; 16: 1-8)$, or it is used in a more generic sense (Lk 19:12).

9.At this point it may be difficult to say with certainty that the $\pi \tilde{\omega}$ in Luke $4: 15,4: 20$ and $4: 36$ are the same group as the $\lambda$ aòs group in Luke 3:21. With the movement from Jordan to Galiee, from Galilee to Nazareth and from Nazareth to Capernaum, from Jordan to Gallee, from Galilee to Nazareth and from Nazareth to Capernaum, it is not only the context that changes, the audience changes as well. Consequently, the $\pi \tilde{a} \zeta$ at this point of the Gospel probably refers to a mixed group formed of onlookers from a Jewish religious context ( $\lambda$ abs), as well as those people who might be convinced of (and therefore have a different feeling about) what Jesus is doing ( $\lambda$ a ós). Their distinction from the other two groups already mentioned as the $\pi \tilde{\alpha}$ may just have originated from this fact - that they were not a homogeneous group. of his ministry (Lk 4:18-19), as well as the presentation of himself as the content of this very ministry (Lk 4:21). They seem to have understood who Jesus was and what it implied for him to be the content of his ministry and, in response, they $(\pi \tilde{a} \varsigma$ ) spoke well of him (Lk 4:22). However, their later association or categorisation of Jesus with Joseph creates a problem, as Jesus does not seem to approve of the identity by which they understand him - for they either (probably) misunderstood him, or they were perplexed by the difference in Jesus' credentials as he presented them in the synagogue and the credentials by which they had always known him (as the son of Joseph) - hence, he dissociates himself from this seemingly distorted identity, now comparing his mission to that of Elijah and Elisha. The $\pi \tilde{\alpha} \varsigma$ probably understood the implication of what Jesus said - that his mission will surely go beyond Israel; causing them to rise against him (Lk 4:29). Therefore, although they seemingly acknowledged Jesus because of the announcements or the pronouncements that he makes, they are still convinced that he is Joseph's son, creating a dissonance between Jesus' presentation of who he is and their expectation of who he should be and what he should do.

The next micro-narrative takes Jesus from Nazareth to Capernaum (Lk 4:31-37), where the $\pi \tilde{\alpha} \varsigma$ is more responsive - they do not seem to have any prior knowledge of or about Jesus; hence, they come to know him through his teachings in the synagogue - and they are astonished because his words have such authority (Lk 4:32). In this situation, Jesus seems to approve of their first impression of him, for, in contrast with his refusal to heal in Nazareth, he heals a man with an unclean spirit by word of mouth. This healing (naturally) reinforces the enthusiasm of the $\pi \tilde{a} \varsigma$ - not only are they amazed, but they also start discussing the meaning of the events as they have transpired. Their general consensus and conclusion is that the authority of Jesus' words comes from within himself; that within him he possesses both the authority and the power to command unclean spirits (Lk 4:36). So, unlike what happened with the $\pi \tilde{\alpha} \varsigma$ in Nazareth, the $\pi \tilde{\alpha} \varsigma$ in Capernaum seem to know and accept Jesus for his preaching and his actions (i.e. healing).

Jesus' fame comes from the authority and power (to heal) that the $\pi \tilde{\alpha} \varsigma$ recognise and that he again confirms (demonstrates) in Simon's house when he admonishes and banishes the fever from which Simon's mother-in-law had been suffering (Lk 4:38-39). Jesus also rebuked the demons for identifying him publicly as the 'Son of God', because they knew that he was the 'Christ' (Lk 4:41). At the same time, it seems that the $\pi \tilde{\alpha} s$ is also starting to develop a new composition - Jesus' actions in Simon's house impressed his audience; consequently, 'all those who had any that were sick with various diseases brought them to him; and he laid his hands on every one of them and healed them' (Lk 4:40).

From this moment onwards, Luke becomes more explicit on who exactly is following Jesus, be it the ö $\chi \lambda$ os or the $\lambda$ a òs, which would, when looking at them again, make it seem that these introductory stories pave the way (are preparatory work) for 
the eventual discovery of who Jesus really is. Firstly, Jesus is baptised at the same time as when the $\lambda$ aòs is being baptised (Lk 3:21), which thus makes them witnesses to the 'voice' that identifies him as God's Son (Lk 3:22). They are also probably part of the group that later becomes the reason for Jesus' fame (Lk 4:15). Yet, there is an interesting exception - when Jesus enters the synagogue in Nazareth and teaches there, he meets another group of $\pi \tilde{\omega} \varsigma$ that receives him with what seems to be a preconceived agenda, for, when what he did and said did not fit with their agenda, they rebelled and rose against him. But, when he proceeds from there to Capernaum, the interest of the $\pi \tilde{\alpha} \varsigma$ in Capernaum only grows when they witness him act with authority and power.

So, at the beginning of Luke's Gospel, the relationship between Jesus and this character group is a relationship marked by self-revealing and self-discovering. Jesus reveals his ministry to the $\pi \tilde{\alpha} \varsigma$, who then immediately recognises or realises who Jesus is. Thus, the fact is that he (Jesus) is the content of his ministry; an embodiment of the authority and power with which he acts. And, whilst those whose minds are free do indeed understand him through his preaching and actions, those who had preconceived knowledge about him feel disappointed and reject him.

\section{Some remarks}

As a result of the above analysis, at least two distinct groups have been identified within the Jewish peasantry - the o' $\chi \lambda$ os and the $\lambda$ aòs. This distinction in groups started with the work and baptism of John the Baptist in Luke 3:7 (Conzelmann 1982:163; Sanders 1987:43); a distinction that became ever clearer throughout the course of Jesus' ministry (Lk 4:42). The o' $\chi \lambda \circ$ s and the $\lambda$ aòs are therefore two distinct character groups, whose attitude towards Jesus as an individual, as well as towards the Jesus movement, are not to be mistaken. If this were to happen, then the author's intentions on this point (with this distinction) will be misunderstood. Through the above analysis it also became clear that any attempt at understanding the way in which the author of the Gospel of Luke uses these distinct terms depends on the understanding that the researcher has of the relationship which Jesus established with each of these individual groups. In Luke's terminology, $\lambda$ às has to do with a specific religious or a particular ethnic group; whereas, ó $\chi \lambda \circ$ s is a group that goes beyond ethnic and religious inclination. The Gospel ends with the $\lambda$ aòs being assimilated into the of $\chi \lambda \circ s$, in those moments when they started beating their chests and returned home (Lk 23:48) - apparently a breaking away from the old religion; from Judaism (a religion of ethnicity) to a new movement later called Christianity (a universal religion).

From an emic perspective, a re-narration of Jesus' story in the Gospel of Luke reveals that the Jewish peasantry (especially the o' $\chi \lambda$ os and the $\lambda$ aoss) are those people who animate Jesus' ministry and lead to his popularity. The most interesting feature of this relationship between Jesus and the different peasant groups lies in the ambivalent nature of the peasantry's attitude on the one hand, and Jesus' responsive attitude, on the other hand.

\section{The Jewish peasantry's ambivalent attitude, in contrast to Jesus' acceptance}

An emic reading of the relationship between Jesus and the Jewish peasantry seems to create confusion in the mind of the modern reader; partly due to exactly this ambivalent attitude in the peasantry which sometimes leads to misunderstanding and eventual misinterpretation of who Jesus is. For example, whilst the Jewish peasantry seem to be positive towards Jesus in Galilee, this is definitely not the case in Jerusalem. What makes this finding even more interesting is the fact that the author of the Gospel of Luke portrays their loyalty towards Jesus as an attitude of opposition vis-à-vis the Jewish elite (Sanders 1987:64). As such, the Jewish peasantry are presented as those who seem to understand Jesus' identity and his ministry, unlike (in contrast to) the religious leaders - who consider him to be a religious rival. Contrary to this fluctuation in the attitude of these two groups, Jesus' attitude towards the different groups in the Jewish peasantry seems to remain stable - he embraces them through his ministry of reformation and transformation. This next section will focus on an elaboration of the Jewish peasantry's acceptance or rejection attitude, in contrast with, or in contrast to, Jesus' attitude of acceptance.

\section{An ambivalent attitude: Acceptance and rejection by the Jewish peasantry}

\section{The Jewish peasantry's opposition to Jesus}

Croissant (1965:190), Sanders (1987:64) and Tyson (1986) are all in agreement when stating that the Jewish peasantry only rejected Jesus in the passion narrative of Luke's Gospel. But an emic reading of the relationship between Jesus and the Jewish peasantry has proven the contrary see argument above), demonstrating that the relationship between Jesus and the different groups within the peasantry is rather a relationship that portrays opposition, rejection and conflict throughout the whole Gospel, from Galilee to Jerusalem.

The first clash that is mentioned in the Gospel is that between Jesus and the Jewish peasantry in Nazareth - the place where Jesus introduces himself and the mission he bears in the synagogue (Lk 4:16-30). ${ }^{10}$ However, before this incident takes place, Jesus' fame had already been established in the surrounding areas of Galilee, where he had taught in many different synagogues (Lk 4:14-15). Whilst in the Nazarene synagogue, his eloquence and his identification with Isaiah's prophecy appears to have energised the peasants (or made them enthusiastic). Hence, they 'all spoke well of him, and wondered at the gracious words which proceeded out of his mouth' (Lk 4:22a). However, this joy is short-lived followed by feelings of suspicion, which function as a symbol of rejection (cf. Neyrey \& Rohrbaugh 2008:243): 'Is not this

10.Tyson (1986:32) describes the micro-narrative of Luke 4:16-30 as programmatic, both for the Gospel of Luke as well as for Acts. According to Tyson, the pericope sets the tone for Jesus' agenda; it announces the themes that will be developed in Luke-Acts and it presents the fate that awaits Jesus in the course of his ministry. It also projects Jesus' future ministry; a ministry which eventually will be handed It also projects Jesus' future ministry; a ministry which eventually will be handed
over to the apostles and the Church as a legacy. The focus of this pericope is Jesus' rejection by his peers. 
Joseph's son?' (Lk 4:22b). Thus, Jesus' earthly identity (as Joseph's son) did not seem to match with the heavenly mission he claimed had been assigned to him. The premise of their critique and opposition is Jesus' genealogy (Lk 3:30).

Jesus' response (Lk 4:23-27) to this remark can be said to have two implications (Nyiawung 2010:236), in that it refers to his person both as an individual and as a member of a dyadic community. As an individual, the issue at stake here is that of Jesus' identity - his status and his origin (Malina 2001:32; Neyrey \& Rohrbaugh 2008:243); especially since his perceived identity seems to be incompatible with what they (the group) know him to be - a peasant's son. Because of this known earthly origin, they ignore his status as 'Son of God', as well as his famous ascribed and acquired identity (honour; Lk 4:14) and his declarations of self-acclaimed identity (Lk 4:18-21). Malina (2001:119) has described this attitude coming from the Jewish peasantry as that of 'envy'11; for, to identify Jesus as Joseph's son was a way of cutting his claim to honour down to size. ${ }^{12}$ But Jesus did not tolerate this approach, for then he would have been identified through the wrong (human) source, that which had put his divine identity into question.

Therefore, the remarks that the peasants made could be interpreted as a sort of ridicule to Jesus' birth status and, through that, an insult to his personality (Rohrbaugh 1995:195). The question (challenge) refers to Jesus as a member of the community; so much so, in fact, that Jesus seems to have found in this question an echo of the issue surrounding boundaries and kinship relations (cf. Gaventa 2008:159). For these peasants, the extension of Jesus' ministry and mission to those outside the 'Jewish boundary' was totally unacceptable. Still, Jesus' corrective reaction instead defines and grants a universal vision to his mission. This became an embarrassment to the Nazarenes; hence, his rejection became apparent and outright.

The Jewish peasantry's second major rejection of Jesus occurs when he performs an exorcism (Lk 11:14-23). As a result, whilst some of the o' $\chi$ dor marvelled, the rest of the populace accused him of conniving with Beelzebul (Lk 11:15) and some even tested him by requesting a sign from heaven. Associating Jesus with Beelzebul was an attempt to label him as a social deviant (Malina \& Neyrey 1991a:120). Similarly, the request for a sign of authenticity was an indication of opposition and rejection; it was a challenge to his honour (Malina \& Neyrey 1991b:49). So Jesus is once again rejected on the basis

11.Jesus' peers knew his earthly background. In this respect, the question: "Is not this Joseph's son?' seems to have been ironical. Traditionally, the Nazarenes knew that Jesus was born into a simple peasant family (Neyrey \& Rohrbaugh 2008:243) Consequently, Joseph's profession (as a carpenter), as well as the circumstances surrounding Jesus' conception, his birth and his naming would not have offered him the dual honourship which he now claimed (Lk 4:21). Jesus' status had suddenly been lifted high above theirs, implying a loss of honour on their part (Rohrbaugh 2000:200-214). As a result, it can be stated that envy made his peers rise against him.

12.In 1st-century Mediterranean society, honour and shame were pivotal values in human relationships (DeMaris \& Leeb 2006:180; DeSilva 2000:23; Downing 200 humin 2000:13; Esler 1994:25; Hanson 2008:39; Malina 2001:27; Moxnes 1996:19; Rohrbaugh 1995:183); to identify Jesus as Joseph's son was a distortion of his identity and a downplaying of the honour ascribed to him at his baptism (LK $3: 21-22$ ). In terms of honour and shame, this was a challenge to Jesus' honour. The appropriate way to regain honour was through the process of challenge-response (Malina 2001:33; Moxnes 1996:20) - an option that Jesus chose. of his identity and his actions and although Jesus may have understood the meaning of their rejection - the intention that was embedded in their appeal - he still described them as 'an evil generation' (Lk 11:29) and as 'hypocrites' (Lk 12:56a) in response to their challenge. In short, Jesus' criticism implies that, though the Jewish peasantry seem to show loyalty, they are in fact unwilling to interpret 'the present time' (Lk 12:56b) - thus illustrating quite clearly that the Jewish peasantry did not understand who Jesus really was, or precisely what he was doing.

Jesus' remarks about the Jewish peasantry's opposition about their hypocritical attitude - are confirmed when they are implicated in his arrest, trial and crucifixion in Jerusalem: the o $\chi \lambda$ os team up with Judas and the religious leaders in order to betray Jesus; they connive with the religious leaders and with Pilate to testify against him (Lk 23:4). The $\lambda$ aòs also become part of this action against Jesus when they join the chief priests, the rulers and the o' $\chi \lambda$ os to press hard on Pilate to condemn Jesus (Lk 23:13-18); it is this last alliance that confirmed their absolute rejection of Jesus, as they requested that he be crucified in lieu et place of Barabbas. ${ }^{13}$ What makes this rejection even worse is the fact that not one of the many individuals from the Jewish peasantry - who had earlier benefited from Jesus' benevolence - stood to testify positively about him during the trial. ${ }^{14}$ At the crucifixion, this same group stood watching whilst the rulers derided Jesus and the soldiers mocked him (Lk 23:35-38); thus they have suddenly become impotent, unlike earlier in the Gospel, where they had been an important source of Jesus' security (see the section entitled 'Jesus' attitude towards the Jewish peasantry' below). The attitude of the rulers and the soldiers, as well as the silence of the Jewish peasantry, was a scornful replay of Jesus' prophecy in Luke 4:23: 'Physician, heal yourself.' As they watched Jesus, they probably expected him to avenge himself, in this way effectively re-assuming the redemptive mission they expected of him (cf. Lk 24:19).

But, in spite of the situation described above, the Jewish peasantry's attitude of rejection should not be understood in the sense of rivalry - as was indeed the case with the attitude of the Jewish elite towards Jesus. No, the Jewish peasantry rejected Jesus because he did not seem to be the person they were expecting him to be, especially because the status that he had claimed for himself had seemed to them to be undeserved. And, even though Jesus had declared and explained his claim and credentials (Lk 4:18), his attitude and his utterances were still viewed (by the Jewish peasantry) as being in sharp contrast with their expectations. This probably

13.At this point of the narrative, the author of the Gospel of Luke describes and probes the relationship between Jesus and the Jewish peasantry. The two major groups that constitute this system are shown to have taken part actively in rejecting and opposing Jesus. Both groups have connived with the Jewish elite and the Roman elite. Consequently, the rejection of Jesus by the Jewish peasantry seems total.

14.In light hereof, Moxnes (1996:20) remarks that public (e.g. the crowd and the people) opinion was important in legitimating an individual's social status. It is for this reason that the contribution of the Jewish peasantry in labelling Jesus as a social deviant should be taken note of. Their testimony against Jesus was crucial for the approval of his rejection. On the other hand, their support for him would have freed him, as it had been the case during his ministry (see the section entitled 'Jesus' attitude towards the Jewish peasantry' below). 
explains why, at various instances through the Gospel, they became ambivalent in expressing loyalty (and at certain times disloyalty) towards Jesus.

\section{The Jewish peasantry's acceptance of Jesus}

The Jewish peasantry expressed their loyalty towards Jesus in two different ways: firstly, they showed open support for Jesus' mission and, secondly, they opposed the Jewish religious authorities - Jesus' major adversaries in the Gospel of Luke - which could be interpreted as a form of loyalty towards Jesus (as will be indicated below). To begin with, as a form of acceptance, the Jewish peasantry spread the word about Jesus - thus raising his fame, honour and esteem - everywhere in the surrounding countryside of Galilee (Lk 4:14-15). In Capernaum, they showed acceptance through their service to him (Lk 4:37-41); thus establishing a relationship of acceptance, emanating from the personal experiences of seeing Jesus' actions.

The loyalty of the Jewish peasantry is also demonstrated in their approval of Jesus' activities: they sought him out even in the loneliest of places (Lk 4:42-44), they constantly gathered to listen to him (Lk 5:1-3; 6:17-19; 8:4; 20:1; 21:38) and then in such great numbers that other peasants were prevented from gaining access to Jesus (Lk 5:15-16; 8:19-21; 19:3-4). A large number from these groups also offered Jesus company, supporting him and rejoicing in what he did $(\operatorname{Lk} 7: 9,11 ; 8: 40$, 42 , 45; 9:11, 37; 11:29; 12:1, 54; 13:17; 14:25; 18:36). They also demonstrated proof of their reliability by addressing Jesus with referential and honourable titles such as 'great prophet' (Lk 7:16), 'Elijah' and 'John the Baptist' (Lk 9:19). ${ }^{15}$ But, in doing so, they became a threat to Jesus' religious rivals (Lk $19: 48 ; 20: 6,19,26 ; 22: 2,6)$.

So, as briefly mentioned above, the Jewish peasantry also supported Jesus by standing up to his main opponents the religious authorities (cf. Kingsbury 1997:156-157). They hung on Jesus' words; in a way becoming Jesus' 'security guards', for their constant presence frustrated the enemy's plans to arrest and kill Jesus. Unfortunately, this attitude seemed to be a wavering one, something which the Jewish religious authorities picked up on fairly quickly. Hence, at the beginning of the passion narrative, they manipulate that very same 'obstacle' (i.e. the Jewish peasantry) in order to gain access to Jesus.

As Jesus' fame grew (Lk 7:17), John the Baptist decided to send his disciples to investigate whether Jesus really was the expected one (Lk 7:18-23). But, rather than respond affirmatively, Jesus instead analyses the relationship between John and himself (Lk 7:24-28). As a result of this analysis,

15.Greene (1980:32) argues that the presentation of Jesus' identity, with reference to prophecy, is part of Luke's literary strategy. In the beginning of the Gospel, Mary and Simeon prophesise about Jesus' identity (Lk 1:46-56; $2: 30-35)$. Anna equally identifies him as being in the line of the redemption of Israel (Lk 2:38). John the aptist's words about Jesus are also prophetic (Lk 3.5-6, 16-18). In the same way, at the end of the Gospel, the disciples on the way to Emmaus present him as the expected prophet (Lk 24:19). In these various presentations, Jesus is described in terms of the functional roles that are likened to the prophetic ministry.
Jesus' audience now responds differently - according to the Gospel's story line:

the people and the tax-collectors justified God having been baptized with the baptism of John; but the Pharisees and the lawyers rejected the purpose of God for themselves, not having been baptized by him.

(Lk 7:29-30, [author's own emphasis] ${ }^{16}$

The conjunction 'but' here plays an adversative role, putting the Jewish peasantry and their leaders against one another with regards to their attitude towards Jesus; it thus compares and contrasts the Jewish peasantry's relationship of acceptance and the Jewish elite's relationship of rejection. This rejection implied the latter's opting out of (or excluding themselves from) God's purpose, which also meant the rejection of their responsibilities as God's brokers (Moxnes 1991:256). Finally, it referred to the rejection of Jesus, who was thus considered a renegade and an outsider (McVann 1991:357). Jesus had presumed that, in comparison with their religious leaders' response, as discussed above, the Jewish peasantry would be more receptive to his ministry (cf. Nyiawung 2010:200), which justifies why he did not mention them as part of those who would eventually participate in his rejection and killing: 'the Son of man must suffer many things, and be rejected by the elders and the chief priests and scribes, and be killed, and on the third day be raised' (Lk 9:22). This is also probably the motivation for the disciples' comments, on the way to Emmaus: 'Our chief priests and rulers delivered him up to be condemned to death, and crucified him' (Lk 24:20). ${ }^{17}$

This brings us to the contrast between the Jewish peasantry's attitude and the attitude of their religious leaders towards Jesus at the crucifixion; a further indication of the fact that their loyalty is (still) towards Jesus - for instance, Luke reports that 'the people stood by, watching; but the rulers scoffed at him' (Lk 23:35). In response, Sanders (1987:67) wonders why the Jewish peasantry, at such a crucial point, would only watch him rather than make an effort to prevent the crucifixion (as they had done before). However, under the circumstances their passive attitude can actually be understood and characterised as an attitude of acceptance, for whilst their allies scoffed at Jesus and challenged his status as a sign of rejection (Malina \& Neyrey 1991a:117), the $\lambda$ às inactively watched him (most probably a sign of their regret). So, even though they no longer actively defend Jesus, they also do not treat him as an opponent or cast further accusations against him either. Jesus certainly understood

16.In these verses, the "people and the tax-collectors' represent the Jewish peasantry in general, whilst 'the Pharisees and the lawyers' stand for the Jewish elite. It is therefore a verse that divides the Jewish people into two distinct camps, with reference to their relationship with Jesus; one being that of acceptance, the other being that of rejection.

17.The account of the circumstances that led to Jesus' death - as reported by the disciples on the way to Emmaus - seems faulty. It ignores the fact that the " $x$ ㅅos took part in the betrayal (Lk 22:37) and rejection (Lk 23:4) and that the $\lambda$ aò shouted for his crucifixion (Lk 23:13-25). Rau (in Sanders 1987:67) seems to support the disciples' comments when he argues that the $\pi \tilde{\alpha} \varsigma$ and the $\pi \lambda \tilde{\eta} \theta_{0} \varsigma$ of Luke 23:1 refer to the Sanhedrin and not to the peasantry per se. This might be an attempt to prove that the peasantry, who were receptive to Jesus mission at the beginning, could not at the same time stand against him in Jerusalem. Notwithstandin the above argument, it remains clearly evident from the emic reading of Jesus' relationship with the Jewish peasantry that - at some points - Jesus was rejected by the peasantry (see argument above) 
their attitude as an act of ignorance; we see him praying to God to 'forgive them; for they know not what they do' (Lk 23:34). Moreover, they finally and fully seemed to have recognised their ignorance and their limitations on their way back home after the crucifixion, 'beating their breasts' (Lk 23:48) as a sign of regret, repentance and acceptance (Marshall 1978:876-877; Tyson 1986:46). In a nutshell, the Jewish peasantry's changing attitude of acceptance or rejection animates the ambivalent nature of their relationship towards Jesus in the Gospel of Luke.

\section{Jesus' attitude towards the Jewish peasantry}

From an etic point of view, Luke's Gospel is written within the context of 1st-century Mediterranean society - a society where the marginalised have been robbed of their rights as sons and daughters of Abraham (cf. Gaventa 2008:152-155). It is for this reason that scholars such as Beavis (1997:142) have described Jesus' mission in Luke as a mission to the socially disadvantaged individuals and groups (cf. Tannehill 1986:103). Generally speaking, Jesus responded to the rejection that he suffered from his contemporaries (i.e. the disciples, the Jewish elite, the Jewish peasantry and the Roman elite) with acceptance; a seemingly natural way of abolishing the existing social and economic inequality among these social groups.

Jesus portrays a general attitude of acceptance towards all the different and varying character groups in Luke's Gospel; just look at, for instance, the indiscriminate forgiveness that he offers on the cross ( $\operatorname{~k~23:34)~-~a~testament~to~his~attitude~}$ of acceptance and compassion, an attitude that was displayed irrespective of the loyalty or disloyalty of his contemporaries. Although he stood firmly against dehumanising structures and attitudes, he did not reject nor discard the culture and practices of his context; no, he chose to form, re-form, transform and inform his society from within - by way of his exemplary teaching and actions and through his attitude. He did not even reject nor ignore individuals; instead, he challenged consciences: 'Go and do likewise' (Lk 10:37; see also Lk 9:14:12-14; 22:14-23).

By rejecting the status quo in this way, Jesus stood in favour of better living conditions for both the peasantry and the elite, attempting to install a society of solidarity and mutual acceptance (Lk 6:27-36); hence, his attack on material possession (Lk 12:13-21; cf. Lk 16:14), as well as his encouragement of generosity, alms giving (Lk 12:32-34) and hospitality (Lk 14:12-14). In this same vein, the parable of the Good Samaritan (Lk 10:25-37) and the story of Lazarus (Lk 16:19-31) both accentuate Jesus' quest for a life of harmony and acceptance, a life where gaps of ethnicity and division are bridged. In this struggle to build a new community, where a society of 'want' (limited good) is transformed into a society of 'abundance' (Nyiawung 2010:338; cf. also Malina 2001:82-105), Jesus manifests an attitude of acceptance, employing two strategies - de-categorisation (which is an aspect of social identity theory) ${ }^{18}$ and 'similarity-attraction'19 (cf. Nyiawung 2010:252-259).

Through de-categorisation, Jesus brings order into a society of disorderliness, where purity laws have become part of societal pressure (Elliott 1991:221; Neyrey 1991). Jesus defies purity laws by associating with sinners and tax collectors (Lk 5:8-10, 27-30; 7:29, 34, 37-39, 15:1-2; 18:9-14; 19:1-10), for his idea of God's kingdom (the new household) destroyed the boundaries of a limited-good-society and declared all goods as available. He thus advocated for a society of unlimited good and the restoration of 'full human life' to the poor (Moxnes 1988:104), enabling him to affirm the fact that all human beings were endowed with the same opportunities because they are all children of Abraham (see Lk 3:8).

By using 'similarity-attraction' Jesus confirms that it is easier to create friendship on the basis of common areas of interest. Consequently, in the parable of the Good Samaritan (Lk 10:25-37), he proves that love and compassion are true virtues inherent to all individuals - irrespective of their ethnic background or inclination; for the Samaritan is presented as a model of good behaviour, a person whose attitude is recommended to the lawyer. Jesus also approves of and welcomes both the crippled woman (Lk 13:10-17) and Zacchaeus (Lk 19:1-10) as daughter and son of Abraham. It is on this basis that they were accorded salvation. Through all of these actions, Jesus narrows the gap between the different social groups found in the context of the Gospel of Luke (Tannehill 1986:103; and Beavis 1997:142); his approach to societal concerns serving as a glimpse into the nature of God's kingdom, which he established in the midst of the Jewish people (Lk 17:21).

\section{Some further remarks}

In spite of the above analysis, the most intriguing questions seem to persist: Why did the Jewish peasantry exhibit an attitude of ambivalence, oscillating between acceptance and rejection throughout the Gospel? Did they understand Jesus at all? What were their intentions?

In effect, as with all other Lukan characters, the Jewish peasantry's attitude should be understood concomitantly with the author of the Gospel of Luke's intentions to show how the various characters developed their understanding of Jesus' identity. Their positive and accepting attitude

18. Social identity theory is a branch of social psychology, largely developed by Hen Tajfel in Britain in the 1970s and 1980s. It studies the relationship between people's self-concept and their membership of groups, dealing with three main aspects: categorisation, identification and comparison (Black 2003; Hogg 1996; Rosel 2008; Tajfel 1986). Categorisation stipulates that people and objects are better understood with reference to the group to which they belong. Unfortunately, in Luke's Gospel, categories were a source of recalcitrant strife exactly because they were formed on the basis of cultural identity. Hence, they generated prejudice, stereotypes, xenophobia and ethnocentristic feelings (Avruch 2003:55; see also Esler 1996:139). As a solution, Jesus used the method of de-categorisation, which is one of the ways to curb conflicts that arise as a result of categorisation (Brown 1996:170-176; Esler 2002:195-199).

19.The theory of 'similarity-attraction' is still another way of curbing conflicts in a stratified society. Rokeach (1960) remarked that people with similar beliefs seemed to attract each other, irrespective of their group differences. This theory, as a method of conflict resolution, encourages points of convergence between as a method of conflict resolution, encourages points of convergence between
social groups to be brought to the fore in matters of conflict resolution, whilst areas of disagreement should be shunned. 
resulted from their appreciation of Jesus' identity, from what he did and what they expected; consequently, when their expectations seemed to fail, they turned against him. However, at the end of the Gospel, their attitude is that of guilt, repentance and mourning (Conzelmann 1982:1520). In response, Jesus' approach of acceptance and tolerance serves as a catalyst to the revealing and understanding of his true identity as 'the Christ, the Son of God' (Lk 9:20).

\section{Conclusion}

At the core of the ambivalent attitude of the Jewish peasantry in their relationship with Jesus lies the question of identity; a question that, in actual fact, animates the whole of Luke's Gospel. Firstly, it is about the question of Jesus' identity: 'Who is this?' (Nyiawung 2010; cf. Culpepper 1995:13; Walker 2001:17-40). Secondly, it is about the identity of those whom Jesus meets - sinners, tax collectors, Pharisees, lawyers, as well as the physically and socially impaired. More than that, it is about the change of identity that takes place because of Jesus' activity, especially the identity of the marginalised (Jewish) peasantry (cf. Gaventa 2008:152-155).

Although the Jewish peasantry followed Jesus and defended him against the threats of the Jewish elite, they seemed to have ignored his identity. And, in spite of the peasantry's rejection of his mission (an attempt to create dissonance within Jesus' ministry), he neither recanted nor feared his mission. Instead, he persevered, persisted and showed acceptance by moulding these same peasants into understanding the essence of his mission. In fact, Jesus remained focused and unperturbed, an indication of the fact that conflict and rejection are not necessarily negative; they are an important ingredient in life (when managed with proper care).

Through this attitude of acceptance, Jesus transformed, reformed and rehabilitated Jewish society, restoring lost hopes. The conflicts that he endured with the various 'systems' of his time (including that of the Jewish peasantry) enabled him to inaugurate a new era of tolerance and mutual acceptance, where social status no longer functioned as a barrier to human relationships. Through this change of identity, he also enabled human beings to regain their lost dignity as children of Abraham. Through the Jewish peasantry's ambivalent attitude, Luke wishes to illustrate or demonstrate that knowledge of Jesus' identity is not static that it grows and varies according to circumstances. This is why it is only at the end of the Gospel that all the different Lukan characters become completely aware (and convinced) of the fact that Jesus is indeed the manifestation of God's presence (Knight 1998:109).

\section{Acknowledgements Competing interests}

The authors declare that they have no financial or personal relationship(s) which may have inappropriately influenced them in writing this article.

\section{Authors' contributions}

This article is based on a PhD thesis of M.D.N. (University of Pretoria) under the supervision of E.v.E. (University of Pretoria).

\section{References}

Avruch, K., 2003, 'Culture', in S. Cheldelin, D. Druckman \& L. Fast (eds.), Conflict, pp. 140-153, Continuum, New York, NY.

Awoh, J., 2003, Advanced level religious studies for Cameroon schools, ANUCAM, Limbe.

Beavis, M.A., 1997, 'Expecting nothing in return: Luke's picture of the marginalized', in J.D. Kingsbury (ed.), Gospel interpretation: Narrative-critical \& social-scientific approaches, pp. 142-154, Trinity Press International, Harrisburg.

Beidelman, T.O., 1970, The Kaguru: A matrilineal people of East Africa, Holt, Rinehart \& Winston, New York, NY.

Black, P.W., 2003, 'Identities', in S. Cheldelin, D. Druckman \& L. Fast (eds.), Conflict, pp. 120-139, Continuum, New York, NY.

Borg, M.J., 2006, Jesus: Uncovering the life, teachings, and relevance of a religious revolutionary, Harper One, New York, NY.

Boulding, K.E., 1957, 'Organisation and conflict', Journal of Conflict Resolution 12, 122-132. http://dx.doi.org/10.1177/002200275700100203

Brown, R.J., 1996, 'Tajfel's contribution to the reduction of intergroup conflict', in W.P. Robinson (ed.), Social groups and identity: Developing the legacy of Henri Tajfel, pp. 169-189, Butterworth Heinemann, Oxford.

Budjac Corvette, B.A., 2007, Conflict management: A practical guide to developing negotiation strategies, Pearson Education, Inc., Upper Saddle River, NJ.

Cassidy, R.J., 1993, 'Reviews the book "Conflict in Luke: Jesus, authorities, disciples" by Jack Dean Kingsbury', Journal of Biblical literature 112(1), 150-152. http:// dx.doi.org/10.2307/3267886

Chouinard, L., 1997, 'Gospel Christology: A study of methodology', in S.E. Porter \& G.A. Evans (eds.), The New Testament interpretation and methods: A Sheffield reader, pp. 65-81, Sheffield Academic Press, Sheffield.

Conzelmann, H., 1982, The theology of St Luke, SCM Press, London.

Craig, J.B. Green \& A.C. Thiselton (eds.), Reading Luke: Interpretation, reflection, formation, pp. 84-99, Paternoster Press, Grand Rapids, MI.

Croissant, D.M., 1965, 'Anti-Semitism and the gospel', Theological Studies 26, 189-214.

Culpepper, R.A., 1995, 'The gospel of Luke: An introduction, commentary and reflections', in M.A. Neil (ed.), The New interpreter's Bible commentary in volumes, vol. IX, pp. 3-490, Abingdon Press, Nashville, TN.

Dahl, N., 1958, 'A people for his name (Acts xv.14)', New Testament Studies 4, 319-327. http://dx.doi.org/10.1017/S0028688500011723

DeMaris, R.E. \& Leeb, C.S., 2006, 'Judges - (dis)honor and ritual enactment: The Jephthah story: Judges 10:16-12:1', in P.F. Esler (ed.), Ancient Israel: The Old Testament in its social context, pp. 177-190, Fortress Press, Minneapolis, MN.

DeSilva, D.A., 2000, Honour, patronage, kinship \& purity: Unlocking New Testament culture, InterVarsity Press, Downers Grove, IL.

Desjardins, M., 1997, Peace, violence and the New Testament, Sheffield Academic Press, Sheffield.

Downing, F.G., 2000, Making sense in (and of) the first Christian century, Sheffield Academic Press, Sheffield

Elliott, J.H., 1991, 'Temple versus household in Luke-Acts: A contrast in social institutions', in J.H. Neyrey (ed.), The social world of Luke-Acts: Models for interpretation, pp. 211-240, Hendrickson Publishers, Peabody, MA.

Elliott, J.H., 1993, What is social scientific criticism?, Fortress Press, Minneapolis, MN

Esler, J.R., 1996, 'Accentuation revisited', in W.P. Robinson (ed.), Social groups and identity: Developing the legacy of Henri Tajfel, pp. 121-142, Butterworth Heinemann, Oxford.

Esler, P.F., 1989, Community and Gospel in Luke-Acts: The social and political motivations of Lucan theology, Cambridge University Press, Cambridge.

Esler, P.F., 2002, 'Jesus and the reduction of intergroup conflict', in S. Wolfgang, B.J. Malina \& G. Theissen (eds.), The social setting of Jesus and the gospels, pp. 185-205, Fortress Press, Minneapolis, MN.

Fitzmyer, J.A., 1985, The gospel according to Luke, Anchor Bible, vol. 2, Doubleday, New York, NY.

Gaventa, B.R., 2008, 'Learning and relearning the identity of Jesus from Luke-Acts', in B.R. Gaventa \& R.B. Hays (eds.), Seeking the identity of Jesus: A pilgrimage, pp. 148-165, Eerdmans Publishing Company, Grand Rapids, MI.

Goheen, M., 2005, 'A critical examination of David Bosch's missional reading of Luke', in G.B. Craig, J.B. Green \& A.C. Thiselton (eds.), Reading Luke: Interpretation, reflection, formation, pp. 55-78, Paternoster Press, Grand Rapids, MI.

Gottwald, N.K. (ed.), 1979, The tribes of Yahweh: A sociology of the religion of liberated Israel, 1250-1050 BCE, Orbis, New York, NY. 
Green, J.B., 2005, 'Learning theological interpretation from Luke', in G.B. Craig, J.B. Green \& A.C. Thiselton (eds.), Reading Luke: Interpretation, reflection, formation, pp. 35-63, Paternoster Press, Grand Rapids, MI.

Greene, G.R., 1980, 'The portrayal of Jesus as prophet in Luke-Acts', unpublished PhD thesis, New Testament Department, University Microfilms International.

Hogg, M.A., 1996, 'Intragroup process, group structure and social identity', in W.P. Robinson (ed.), Social groups and identity: Developing the legacy of Henri Tajfel, pp. 65-93, Butterworth Heinemann, Oxford.

Horsley, R.A., 1993, Jesus and the spiral of violence: Popular Jewish resistance in Roman Palestine, Fortress Press, Minneapolis, MN

Jane Via, E., 1983, 'According to Luke, who put Jesus to death?', in R.J. Cassidy \& P.J. Scharper, Political issues in Luke-Acts, pp. 122-145, Orbis Books, Maryknoll, NY.

Karris, R.J., 1979, What are they saying about Luke and Acts? A theology of the faithful God, Paulist Press, New York, NY.

Karris, R.J., 1985, Luke, artist and theologian: Luke's passion account as literature, Paulist Press, New York, NY

Kingsbury, J.D., 1997, 'The plot of Luke's story of Jesus', in J.D. Kingsbury (ed.), Gospe interpretation: Narrative-critical and social-scientific approaches, pp. 155-165, Trinity Press International, Harrisburg, PA.

Knight, J., 1998, Luke's gospel, Routledge, London.

Malina, B.J., 2001, The New Testament world: Insights from cultural anthropology, 3rd edn., Westminster John Knox Press, Louisville, TN.

Malina, B.J. \& Neyrey, J.H., 1991a, 'Conflict in Luke-Acts: Labelling and deviance theory', in J.H. Neyrey (ed.), The social world of Luke-Acts: Models for interpretation, pp. 97-122, Hendrickson Publishers, Peabody, MA

Malina, B.J. \& Neyrey, J.H., 1991b, 'Honor and shame in Luke-Acts: Pivotal values of the Mediterranean world', in J.H. Neyrey (ed.), The social world of Luke-Acts: Models for interpretation, pp. 25-65, Hendrickson Publishers, Peabody, MA.

Marshall, I.H., 1978, The Gospel of Luke: A commentary on the Greek text, Eerdmans, Grand Rapids, MI.

McVann, M., 1991, 'Rituals of status transformation in Luke-Acts: The case of Jesus the prophet', in J.H. Neyrey (ed.), The social world of Luke-Acts: Models for interpretation, pp. 333-360, Hendrickson Publishers, Peabody, MA.

Moxnes, H., 1988, The economy of the kingdom: Social conflicts and economic relations in Luke's gospel, Fortress Press, Philadelphia, PA.

Moxnes, H., 1991, 'Patron-client relations and the new community in Luke-Acts', in J.H. Neyrey (ed.), The social world of Luke-Acts: Models for interpretation, pp. 241-268, Hendrickson Publishers, Peabody, MA

Moxnes, H., 1996, 'Honor and shame', in R. Rohrbaugh (ed.), The social scientific and New Testament interpretation, pp. 19-40, Hendrickson Publishers, Peabody, MA.

Neyrey, J.H., 1991, 'The symbolic universe of Luke-Acts: "They turn the world upside down"', in J.H. Neyrey (ed.), The social world of Luke-Acts: Models for interpretation, pp. 271-304, Hendrickson Publishers, Peabody, MA.

Neyrey, J.H. \& Rohrbaugh, R.L., 2008, "'He must increase, I must decrease" (John 3:30): A cultural and social interpretation', in J.H. Neyrey \& E.C. Stewart (eds.) The social world of the New Testament: Insights and models, pp. 237-251, Hendrickson Publishers, Peabody, MA.
Nestle-Aland, 1998, Greek-English New Testament, XXVII edn., Deutsche Bibelgesellschaft, Stuttgart.

Nyiawung, M.D., 2010, 'Who is the Christ? Leadership and conflict in Luke 9:18-22: A social scientific- and narratological analysis from an African perspective', unpublished PhD thesis, Department of New Testament Studies, University of Pretoria.

Oakman, D.E., 2008, Jesus and the peasants, Cascade Books, Eugene, OR.

Resseguie, J.L., 2005, Narrative criticism of the New Testament: An introduction, Bake Academic Press, Grand Rapids, MI.

Rohrbaugh, R.L., 1995, 'Legitimating sonship - A test of honour: A social-scientific study of Luke 4:1-30', in P.F. Esler (ed.), Modelling early Christianity: Socialscientific studies of the New Testament in its context, pp. 183-197, Routledge, London.

Rohrbaugh, R.L., 2000, 'Locating Jesus: Strategies for persuasion', in P.F. Esler (ed.), The New Testament world, pp. 198-230, Routledge, London.

Rohrbaugh, R.L., 2007, The New Testament in cross-cultural perspective, Cascade Books, Eugene, OR.

Rokeach, M., 1960, The open and closed mind, Basic Books, New York, NY.

Rosell, S.N., 2008, 'Have this mind: A social-scientific reading of Philippians 2:5-11' unpublished PhD thesis, Department of New Testament Studies, University of Pretoria.

Sanders, J.T., 1987, The Jews in Luke-Acts, Fortress Press, Philadelphia, PA.

Spencer, S.F., 2005, 'Preparing the way of the Lord. Introducing and interpreting Luke's narrative: A response to David Wenham', in G.B. Craig, J.B. Green \& A.C. Thiselton (eds.), Reading Luke: Interpretation, reflection, formation, pp. 64-83, Paternoster Press, Grand Rapids, MI.

Tajfel, H., 1986, 'The social identity theory of intergroup conflict', in S. Worchel \& W.G. Austin (eds.), Psychology of intergroup relations, pp. 7-24, Nelson-Hall, Chicago, IL.

Tannehill, R., 1986, The narrative unity of Luke-Acts, Fortress Press, Philadelphia, PA.

Tyler, T.R., 2005, 'Managing conflicts of interest within organizations: Does activating social values change the impact of self-interest on behavior?', in D.A. Moore, D.M. Cain, G. Loewenstein \& M.H. Bazerman (eds.), Conflicts of interest: Challenges Cain, G. Loewenstein \& M.H. Bazerman (eds.), Conflicts of interest: Challenges and solutions in business, law, medicine, and public policy, pp. 13-35, Cambridge
University Press, Cambridge. http://dx.doi.org/10.1017/CBO9780511610332.002

Tyson, J.B., 1986, The death of Jesus in Luke-Acts, University of South Carolina Press, Columbia, SC.

Van Aarde, A.G., 2006, 'Ebionite Tendencies in the Jesus Tradition: The Infancy Gospel of Thomas, Interpreted from the perspective of Ethnic Identity', Neotestamentica 40(2), 353-382.

Van Eck, E., 1995, Galilee and Jerusalem in Mark's story of Jesus: A narratological and scientific reading, Teologiese Studies/Theological Studies suppl. 7, Kital, Pretoria.

Walker, T.W., 2001, Luke: Interpretation, Bible Studies, Geneva Press, Louisville, KY.

Wenham, D., 2005, 'The purpose of Luke-Acts: Israel in the context of Roman Empire', in G.B. 